\title{
The Level of Necessity and Mental Readiness by Fashion Department Students in Supporting Fashion Business Incubator
}

\author{
Sri Endah Wahyuningsih ${ }^{1}$ \\ ${ }^{I}$ Department of Home Economics, Semarang State University, Semarang, Indonesia \\ s.endah32@mail.unnes.ac.id
}

Keywords: Level of necessity, mental readiness for entrepreneurship, fashion department students, business incubator, higher education.

Abstract: UNNES is an institution of higher education which declares to become an independent legal institution for higher education. The development of entrepreneurship in higher education should have support concerning the aim of Higher Education in Act Number 12 the Year 2012. The Act mentions that higher education should produce faithful and obedient human with nobility, healthy life, skilful trait, creativity, independent, competent, and culturally sensitive for the sake of national development. Entrepreneurship and innovation is an excellent program of UNNES, particularly the Faculty of Engineering, to prepare graduates who can produce creative and innovative products. Entrepreneur education is a compulsory subject in UNNES. The Family Welfare Education Department of Faculty of Engineering is the only department which targets on incubating a lot of business and escalating the number of entrepreneurs in UNNES. The program itself has already initiated a fashion production unit called Sekar Ayu to support students' entrepreneurship. Many researchers and writers consider that the success of an entrepreneur heavily depends on the mentality of the entrepreneur. There are some principles of an energetic entrepreneur, which are: confidence, initiatives, achievement-oriented, leadership, risk-taking, committed, originality, and mastery in management. This study describes the needs and mental readiness for starting an entrepreneurship career, specifically for students from the fashion department, in supporting the department's initiatives of supporting fashion business incubators. The research employed a quantitative approach which inquired 112 students. The researchers gathered data by distributing questionnaires and interview as well as documenting the data with the description of percentage. The results show that the students have a high mentality of entrepreneurship in a score of $74.46 \%$. The 2017-batch students have better mentality comparing to 2016, 2015, and 2014 ones, considering their capability in taking business opportunities and initiating it. The level of incubator development is also high. In conclusion, there is a high interest and strong mentality of Fashion department students in supporting the Fashion business incubator. Further, there should be a development of the incubator supported by all parties in the university.

\section{INTRODUCTION}

The goal of higher education is established in Act Number 12 the Year 2012, which to become a faithful and obedient human to God with nobility, healthy life, skilful trait, creativity, independent, competent, and culturally sensitive for the sake of national development. To support the goal, students have to educate themselves. Entrepreneurship education helps them to achieve the goal. The education, portrayed as a university subject, supports students building their entrepreneurship character and enhances them with required soft skills and hard skills. Hence, after completing the unit, the students can take the chances to develop their own business.

The Directorate of Teaching and Learning for Higher Education (2013:3\&11) explains that entrepreneurship education aims to be able to make students understand, apply, and use entrepreneurship as a living goal. The education also equips the students with soft skills, like the ability to communicate, leading, and managing business ideas properly in society. 
The development of Small and Medium Enterprises is very potential to develop the national economy in the free trade era. McClelland (1987) argues that a country will quickly grow if they have $2 \%$ of its citizens work as entrepreneurs. However, Global Entrepreneurship Monitor (2010) presents that Indonesia only has $0.18 \%$ of citizens working in the respective fields.

In UNNES, the Faculty of Engineering, particularly the Family Welfare Education program uses the National Standard Curriculum of Higher Education and UNNES' curriculum of conservation in 2015. The students are prepared to be a Vocational School teacher with the ability to teach theoretical and practical materials to students. Concerning fashion department, the students are taught practical teaching skills to tutor how to create a pattern, give accessories, add some touch, do screen printing, measure body size, analyze products' quality, and manage fashion industry. All these skills are essential to building entrepreneur character in students' mind. Currently, many graduates work as a public school or private school teacher, which limits students' income and a chance for entrepreneurship. The characters of entrepreneurship are creative, independent, brave to take risk, futuristic, wise, committed, motivating, and innovative (Directorate of Higher Education, 2013:34-35). UNNES focuses on building eight characters, which are inspiring, honest, humanist, care, innovative, sportive, creative, and just. This research focuses on the building of confidence, initiative, achievement-oriented, leadership, risktaking, originality, committed, and mastery in management. SE Wahyuningsih (2018: 119) develops the character of entrepreneurship based on honesty, confidence, inspiration, disciplines, taskoriented, sensitive, creative, opportunistic, cooperative, leading, brave to take risk, selfmanagement, innovation, and independence.

Some students are real potentials in supporting the business incubator as their training for entrepreneurship. The Family Welfare Department of UNNES as established an in an incubator for boutique and culinary. This year, the Faculty of Engineering boosts the business incubator program by focusing more on entrepreneurship and innovation. The Faculty prepares graduates to be able to manage a business with support in a compulsory subject called techno-preneurship.

From the initial research, there are some obstacles to the development of incubators' model and mechanism, which are (1) lack of networking; (2) marketing; (3) bureaucracy; (4) mentality of entrepreneurship; and (5) legality. Rokhani Hasbullah et al. (2015\} shows that most Incubators in higher education has proper performance (75) and only a few of them working well (17) and excellent (8). The incubator also has some limits in terms of process, quality, and infrastructure of incubation. There is also a limit to financial independence.

The problem is faced altogether by Indonesian universities. Besides, there is also a minimum attempt to instil the idea of entrepreneurship mentality. The incubator of business for higher education should be able to develop the market in society to become a profit centre.

To foster the aim of becoming a legal independent higher education, there should be an upgrade to the management system in the university. The institution plans to maintain the life or business of a university so that there will be a synergy between academic and business needs. The business incubator will play a significant role in improving the performance of tenant, where the tenant will have a rise in workers, income, market sector, and the access of autonomy and decentralization of education.

UNNES declares to become an independent university. All departments have to have income generic to support the goal. In this case, the Family Welfare Department utilizes the facilities and infrastructures to develop and achieve the goal. To support this development, there should be a readiness from all parties, including the lecturers, educators, and students.

In the department, the Fashion and Culinary program have initiated incubators to train students entrepreneurship. There is a gap of optimum management to the incubators to sell innovative and creative products. Hence, this research formulates the answer to a question: "How to describe the character of entrepreneurship by students of the Fashion Department in UNNES to support the Fashion Business Incubator in UNNES?".

\section{RESEARCH METHODS}

This research uses a survey and description of the percentage. The study focuses on the students in the Family Welfare education program and Fashion department. The sample was taken using the Table of Sample by Isaac and Michael from a population with a $10 \%$ rate of mistake (Sugiyono, 2015: 71). The population in this research has 230 students with a sample of 125 students. The researcher collected the data using a questionnaire and interview. The data were analyzed descriptively within this research.

\section{RESULTS AND DISCUSSION}

The description of the needs' development in UNNES' fashion business incubator 


\section{BATCH 2014}

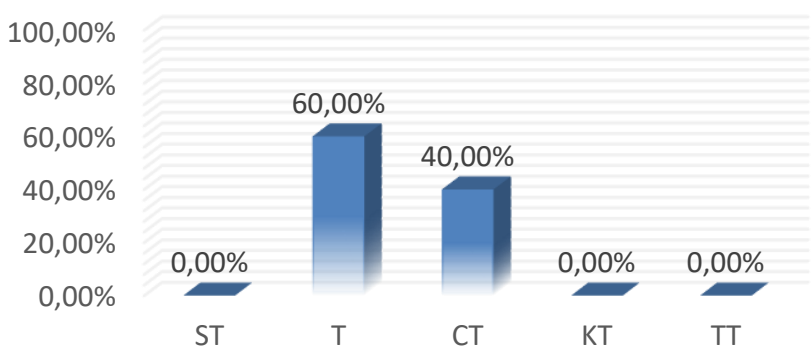

Figure 1. Descriptive statistic fashion business incubator for the 2014 batch

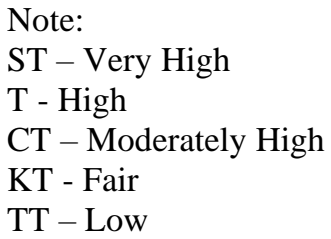

Table 1. Developing fashion business incubator for the 2014 batch

\begin{tabular}{|c|c|c|c|c|c|}
\hline \multicolumn{5}{|c|}{ TOTAL } & \multirow{2}{*}{$\begin{array}{c}\text { OVERALL } \\
\text { TOTAL }\end{array}$} \\
\cline { 1 - 5 } VH & H & MH & F & L & \\
\hline 0 & 9 & 6 & 0 & 0 & 15 \\
\hline $0.00 \%$ & $60.00 \%$ & $40.00 \%$ & $0.00 \%$ & $0.00 \%$ & $100.00 \%$ \\
\hline
\end{tabular}

The researchers surveyed 15 respondents from the 2014 batch. The students had 60\% (high criteria) responses for the needs of a business incubator support in the fashion industry. Whereas, six respondents $(40 \%)$ is in moderately high standards for the needs.

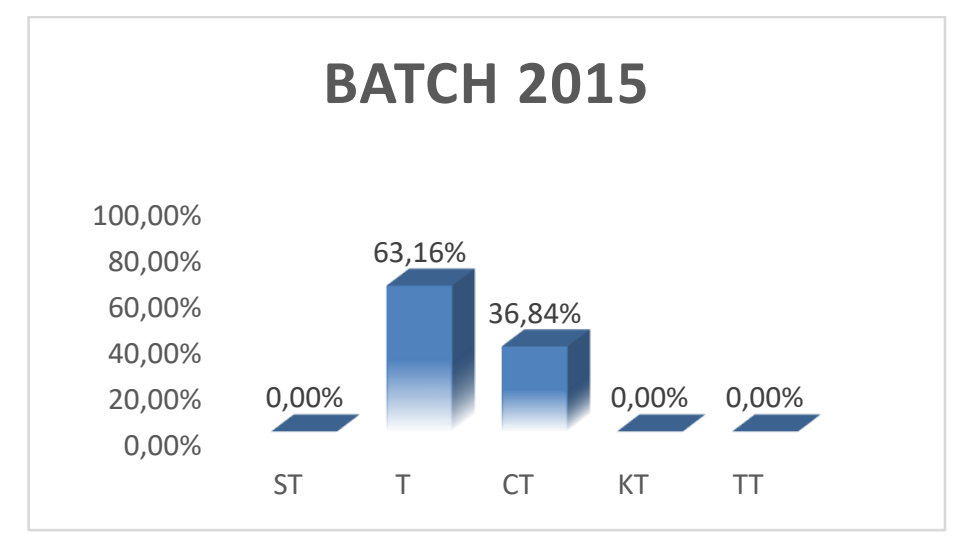

Figure 2. Descriptive statistic fashion business incubator for the 2015 batch 
Table 2. Developing fashion business incubator for the 2015 batch

\begin{tabular}{|c|c|c|c|c|c|}
\hline \multicolumn{5}{|c|}{ TOTAL } & \multirow{2}{*}{$\begin{array}{c}\text { OVERALL } \\
\text { TOTAL }\end{array}$} \\
\cline { 1 - 5 } VH & H & MH & F & L & \\
\hline 0 & 12 & 7 & 0 & 0 & 19 \\
\hline $0.00 \%$ & $63.16 \%$ & $36.84 \%$ & $0.00 \%$ & $0.00 \%$ & $100.00 \%$ \\
\hline
\end{tabular}

responded as high $(63.16 \%)$, and seven

The survey of needs for developing fashion respondents $(36.84 \%)$ were moderately high. business incubator for the 2015 batch students occurred to 19 students. There are 12 respondents

\section{BATCH 2016}

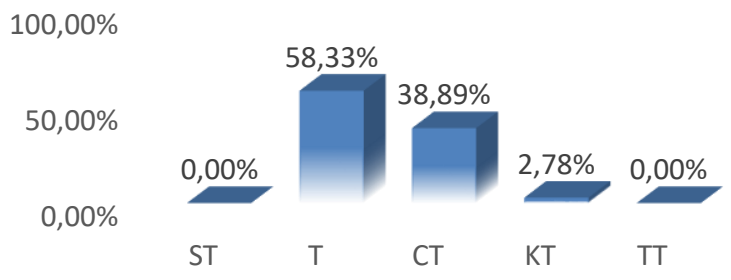

Figure 3. Descriptive statistic fashion business incubator for the 2016 batch

Table 3. Developing fashion business incubator for the 2016 batch

\begin{tabular}{|c|c|c|c|c|c|}
\hline \multicolumn{5}{|c|}{ TOTAL } & \multirow{2}{*}{$\begin{array}{c}\text { OVERALL } \\
\text { TOTAL }\end{array}$} \\
\cline { 1 - 5 } VH & H & MH & F & L & \\
\hline 0 & 21 & 14 & 1 & 0 & 36 \\
\cline { 1 - 4 } $0.00 \%$ & $58.33 \%$ & $38.89 \%$ & $2.78 \%$ & $0.00 \%$ & $100.00 \%$ \\
\hline
\end{tabular}

The researchers surveyed 36 respondents from the 2016 batch students. Twenty-one students responded in a high category $(58.33 \%), 14$ in moderately high $(38.89 \%)$, and one respondent in the percentage of fair $(2.78 \%)$. 


\section{BATCH 2017}

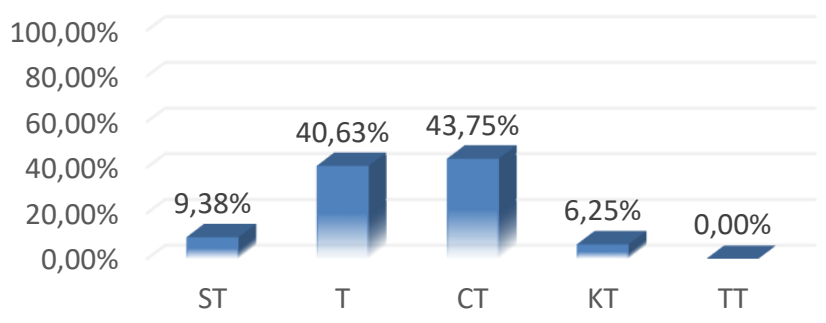

Figure 4. Descriptive statistic fashion business incubator for the 2017 batch

Table 4. Developing fashion business incubator for the 2017 batch

\begin{tabular}{|c|c|c|c|c|c|}
\hline \multicolumn{5}{|c|}{ TOTAL } & $\begin{array}{c}\text { OVERALL } \\
\text { TOTAL }\end{array}$ \\
\cline { 1 - 5 } VH & H & MH & F & L & \\
\hline 3 & 13 & 14 & 2 & 0 & 32 \\
\hline $9.38 \%$ & $40.63 \%$ & $43.75 \%$ & $6.25 \%$ & $0.00 \%$ & $100.00 \%$ \\
\hline
\end{tabular}

There are 32 respondents from the 2017-batch Three respondents answered in a very high category $(9.38 \%), 13$ respondents in a high group
(40.63\%), 14 respondents were in a fair group $(43.75 \%)$, and two respondents were in a low category $(6.25 \%)$.

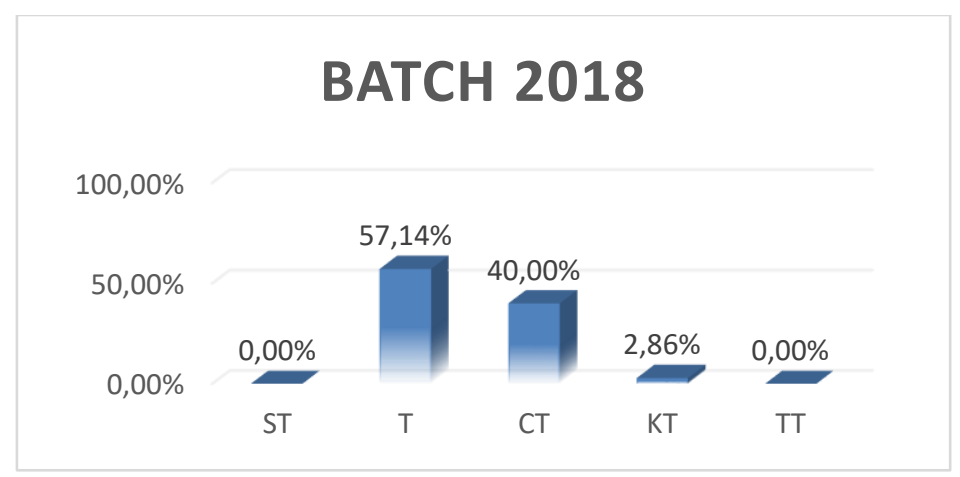

Figure 5. Descriptive statistic fashion business incubator for the 2018 batch

Table 5. Developing fashion business incubator for the 2018 batch

\begin{tabular}{|c|c|c|c|c|c|}
\hline \multicolumn{7}{|c|}{ TOTAL } & \multirow{2}{*}{$\begin{array}{c}\text { OVERALL } \\
\text { TOTAL }\end{array}$} \\
\cline { 1 - 5 } VH & H & MH & F & L & \\
\hline 0 & 20 & 14 & 1 & 0 & 35 \\
\hline $0.00 \%$ & $57.14 \%$ & $40.00 \%$ & $2.86 \%$ & $0.00 \%$ & $100.00 \%$ \\
\hline
\end{tabular}

The researchers took 35 respondents from the 2018 batch-students. Twenty respondents are responding as high $(57.14 \%), 14$ respondents as fair $(40 \%)$, and one respondent as low $(2.86 \%)$.
The Description of Students' Entrepreneurship Mentality

The following table shows students' entrepreneurship mental readiness. 
Table 6. Students' Mental of Entrepreneurship in Each Indicator

\begin{tabular}{|c|c|c|}
\hline Indicators & Percentage & Criteria \\
\hline Confidence & $69.92 \%$ & High \\
\hline Initiative & $71.43 \%$ & High \\
\hline Achievement-oriented & $81.21 \%$ & High \\
\hline Leadership & $72.66 \%$ & High \\
\hline Risk-taking & $73.05 \%$ & High \\
\hline Commitment & $75.78 \%$ & High \\
\hline Originality & $75.00 \%$ & High \\
\hline Managerial capability & $70.71 \%$ & High \\
\hline Average & $74.46 \%$ & High \\
\hline
\end{tabular}

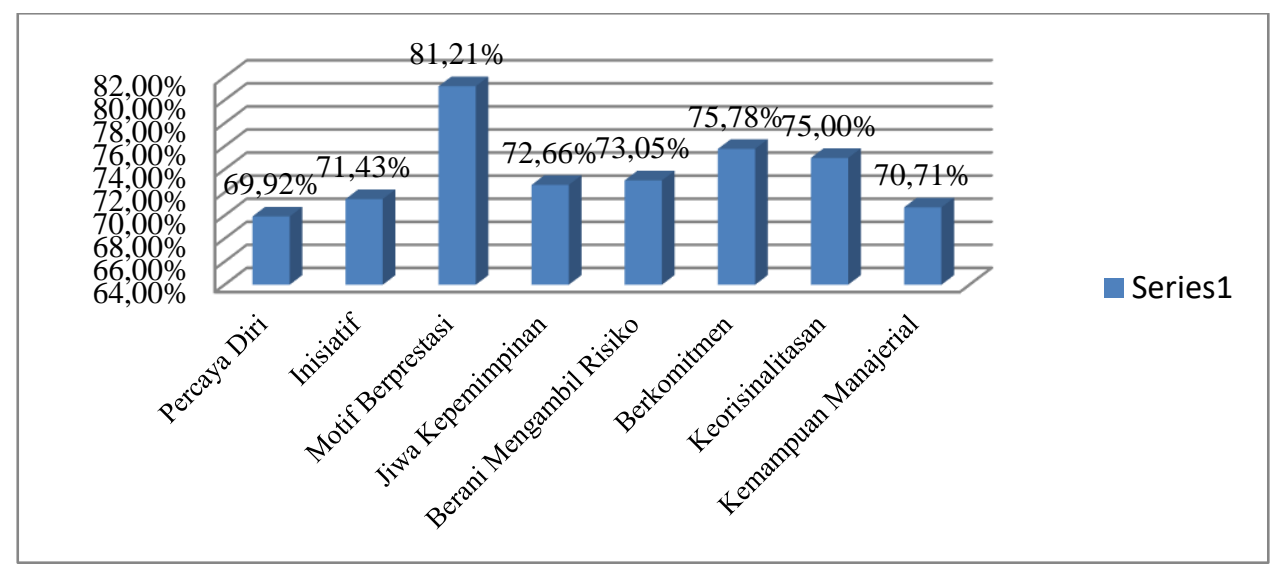

Figure 6. Students' Diagram of Mental of Entrepreneurship

Note:

(Research Questionnaire, 2018)

Percaya Diri $=$ Confidence

Inisiatif= Initiative

Motif Berprestasi $=$ Achievement-oriented

Kepemimpinan $=$ Leadership

Berani Mengambil resiko $=$ Risk-taking

Berkomitmen $=$ Commitment

Keoriginalitasan $=$ Originality

Kemampuan managerial $=$ Managerial capability

The diagram shows all indicators of entrepreneurship mental. Overall, the students have a high status of mentality. The lowest indicator is confidence, with a score of $69.92 \%$. Meanwhile, the highest one is achievement-oriented, with $81.21 \%$.

\section{Discussion}

Confidence is the ability of people to believe in themselves to achieve success (Zimmerer in
Suryana, 2014: 39). Students have a high level of confidence shown from their bravery in expressing their opinion and to ask questions in public. Students also follow organization which supports them to communicate and socialize to many people.

In this research, confidence can develop through training. Wahyuningsih (2014: 54) opines that confidence is not talent. Instead, it is a quality which can be trained or habituated through education.

Students' initiative helps them resolve problems. They can solve an academic problem by 
asking their friends or contacting their lecturers for help. They also remind their friends regarding their responsibility, such as daily tasks and marketing practical products from their class projects. Students formed their initiatives by training and experience a real working situation. The occurrences prepare them to be disciplined, critical, passionate, and productive (Kemendikbud, 2014: 49).

Achievement-oriented is a social value which emphasized on reaching the best outcome for personal satisfaction (Suhandana in Suryana, 2014: 49). Students' motive can be seen from their interest to be higher than the other. They also try to compete in different competitions and target themselves to be graduated on time. Every individual has a passion for getting achievements. As in Mustaqim (2017: 138), motivation and passion encourage people to be able to perform and do their best.

Nugroho (2012: 5) mentions that people's managerial skills include: business planning, independence, working accuracy, cooperation, and evaluation. Students have excellent managerial skills portrayed from their scheduling, the organization of personal laboratory tools, budgeting, and evaluation of activities.

Students' entrepreneurship skills are not only based on their age and units. They become entrepreneurs through learning and experiences. As in Kume, et al. (2013: 22) "to be an entrepreneur does not need any extraordinary talent; it needs some skills that most students process (or can develop), initiative, imagination, a clear vision and confidence". Students will have a difference reflected from their creativity, organizational experiences, and self-entrepreneurial experiences.

There are some factors influencing students' entrepreneur skills, which are their interest, talent, gene, education, experience, personal problem, activities, environments, and their friends. Students can develop their skills through education. Wahyuningsih et al., (2018:459-460) concludes that "model of entrepreneurship-based entrepreneurship education management can be used effectively to enhance the entrepreneurial character, knowledge and skill,". Wahyuningsih (2018: I2.30) also mentions that the characters of entrepreneurship are ethical, creative, and explorative. She also suggests that "the increase of Gain score, which is considered high, thus it is effective".

\section{CONCLUSION}

In conclusion, the students of UNNES' Fashion department has a strong mentality of entrepreneurship with a percentage of $74.46 \%$.
Commitment is the ability of people to work with perseverance and never give up (Suryana, 2014: 24). Students have firm commitments reflected from their habit of sacrificing their nights to finish their assignment, do their homework accordingly, and complete their job on time. The idea is similar to Fink et al., in Moloi and NkhahleRapita (2014: 82) that "commitment is the willingness of entrepreneurs to be engaged in their businesses by working hard as well as sacrificing their family time and money and reducing their standard of living".

Originality is the creativity and innovation of an entrepreneur. Students show their originality by doing their assignment themselves, imagining something from the real world, and to write their ideas on the book or phone. Creativity continuously grows when students face problems. In this case, the issues will be able to inspire students from the Fashion department to produce many original and creative arts.

They portray a high necessity of building their production unit in the fashion industry. The researchers suggest that students, lecturers, and educators should support the fashion business incubators in UNNES to increase the number of entrepreneurs from the graduates.

\section{REFERENCES}

Ditjen Pendidikan Tinggi. (2013). Kewirausahaan Modul Pembelajaran. Jakarta: Dikti.

Harfandi. (2014). Menggali Potensi Jiwa Kewirausahaan Mahasiswa PTAIN di Sumatera Barat. Jurnal Al 'Adl, 7(2), 125-144.

Kisbowoh. (2018). Dorong Pengembangan Wirausaha. Semarang: FT UNNES.

Kume, A., Kume, V. and Assoc, S. (2013). Entreprenurial Characteristics Amongst University Students in Albania. European Scientific Journal, 19(16), 206-225.

Murugesan, R., and Jayavelu, R. (2017). The influence of Big Five Personality Traits and Self-efficacy on Entrepreneurial Intention: The Role of Gender. Journal of Entrepreneurship and Innovation in Emerging Economics, 3(1), 41-61.

Maulana, H. (2018). Pengembangan Jiwa Kewirausahaan: Studi Kasus Terhadap Mahasiswa yang Berwirausaha di Yogyakarta. Jurnal Ecodomica, 2(1), 21-29.

Moloi, P.K. and Nkhahle-Rapita, M.M. (2014). The Impact of Fashion Entrepreneurs' Traits on the Succes of Fashion Businesses in the Gauteng Province in South Africa. Mediterranean Journal of Social Science, 5(4), 78-86.

Mustaqim, M. (2017). Membangun Intensi Wirausaha Mahasiswa: Studi pada Mahasiswa Prodi MBS dan ES STAIN Kudus. Jurnal Ekonomi Syariah, 5(1), 134-149.

Nishanthi, H.M. (2014). Analysis of Entrepreneurial Traits of The Small Business Owners in Sri Lanka. 
International Journal of Scientific and Research Publications, 4(10), 1-7.

Nugroho, T.R.D.A. (2012). Karakteristik Jiwa Kewirausahaan Mahasiswa Universitas Trunojoyo Madura. Jurnal Ekonomi, 1(2), 1-6.

Suryana. (2014). Kewirausahaan: Kiat dan Proses Menuju Sukses. Jakarta: Salemba Empat.

Wahyuningsih, S.E., et al. (2018). Model of Local Excellence for Prospective Vocational School Teachers. International Journal Innovation and Learning, 24(4), 448-461. 